\title{
CASE STUDIES AS A LEARNING METHOD: THE EXAMPLE OF TOURISM CRISIS MANAGEMENT IN JORDAN
}

\author{
Mairna H. MUSTAFA* \\ Department of Sustainable Tourism, Hashemite University \\ P.O. Box 330127 Postal Code 13115 Zarqa, Jordan, e-mail: mairna@ @u.edu.jo
}

\begin{abstract}
Citation: Mustafa, M. (2021). CASE STUDIES AS A LEARNING METHOD: THE EXAMPLE OF TOURISM CRISIS MANAGEMENT IN JORDAN. Analele Universităţii din Oradea, Seria Geografie, 31(2), 89-99. https://doi.org/10.30892/auog.312101-859
\end{abstract}

\begin{abstract}
This paper aims at testing the significance of using case studies as a teaching method for the topic of "Tourism Crisis Management". The case of Arab Spring influence on Jordanian Tourism was selected for this purpose. A sample of 42 students in a Tourism Management BA Program filled a questionnaire, it focused on measuring knowledge of students about the influence of Arab Spring crisis on both the image of Jordan as a tourism destination, and Jordanian tourism economic indicators, also evaluating the performance of tourism stakeholders in the time of crisis. By conducting a paired t-test for responses before and after presenting the case study to students by the instructor, significant statistical differences were found for most of the measured variables, which supports the importance of case studies in making students more aware of political crises' effect on tourism levels, and how to reduce their influences and retrieve the positive image of destinations.
\end{abstract}

Key words: case studies, teaching methods, crisis management, Arab Spring, tourism sector performance, Jordan

$$
* \quad * \quad * \quad * \quad * \quad *
$$

\section{INTRODUCTION}

Making students involved in the learning process ensures its effectiveness (Sivan, Wong Leung, Woon, \& Kember, 2000); the use of case studies which are interactive in nature, makes a teacher-centered learning process become more student-centered (Grant, 1997). A case study is a "story with a hidden message or a narrative that describes an actual or realistic situation in which an individual or a group has to make a decision or solve a problem" (Killen, 2006, p. 275). Case studies increase students' motivation and their interest in subjects (Mustoe \& Croft, 1999), stimulate dialogue (Badger, 2010), link between theory and practice (Olkun, Altun, \& Deryakulu, 2009), encourage deep learning, promote interaction between teachers and students, make learning more enjoyable (Ngcobo, 2008), and promote the development of analytical skills by students (Herreid, Schiller, Herreid, \& Wright, 2011). Case studies can be formal written cases, newspaper articles, movie clips, media news story, pictures, mathematical word problems, pieces of art, or any other (Golich, Boyer, Franco, \& Lamy, 2000). Regardless of their form, case studies facilitate development of the higher levels of 
Bloom's taxonomy of cognitive learning, moving from remembering of knowledge to analysis, evaluation, and creation (Bloom, Engelhart, Furst, Hill, \& Krathwohl, 1956; Anderson \& Krathwohl, 2000). This comes from the fact that they take many forms, these are: critical incidents that are short and compact cases that focus on one event or issue with little contexts; descriptive illustrations that describe actions taken by an organization; problem-identification cases that help students to prioritize information and identify, define, or re-define a problem; decision-focused cases that ask the reader to make a decision or give advice on decisions to be made; application cases where students apply a concept, theory, typology, calculation, or a model to test the fitness of theory to data; contextual issue cases used to explore the context around an ethical and/or legal issue; live cases where information is provided orally in a field visit or a classroom; and multimedia cases that engage students at different cognitive levels (McGuire \& Whaley, 2017).

The significance of using case studies approach in teaching was discussed in previous studies for different disciplines as: chemistry (Bennett \& Cornely, 2001; Cheng, 1995); biology (Camill, 2000); physiology (Cliff, 2006); biochemistry (Cornely, 1998); medicine (Dayal, et al., 2008; Sandstorm, 2006); engineering (Yadav, Shaver, \& Meckl, 2010; Woods, 1996); environment (Biegel, Lee, \& Graveel, 1998), economics (Carlson \& Schodt, 1995), accounting (Knechel, 1992); and psychology (Mayo, 2004). One of the topics that was investigated as well in literature but on a small scale is using case studies in teaching crisis management (e.g. campus crisis management (Shaw, 2018); business public relations (Budden \& Budden, 2010); the role of social workers in responding to crisis (Gelman \& Mirabito, 2005); and ethical response to organizational crises (Key, 1997)). In these few previously mentioned studies, case studies proved to be an effective teaching method. Though, there is a gap in research about the significance of using case studies in teaching such vital topic; especially what relates to tourism sector. The case study of Arab Spring influence on Jordanian tourism was selected to test the effectiveness of using case studies as a teaching method in a course entitled (Tourism Crises Management), which is a compulsory requirement in a BA Tourism Management Program which is offered by a Jordanian Public University. The aim of this course is to make students familiar with the definition and types of crises, the different stages of crisis management, and the role of different sectors in dealing with tourism crises. The following section explains political crisis influence on tourism destinations, followed then by a presentation about the case of Arab Spring and its influence on Jordanian tourism, and how it was manipulated for the above-mentioned course.

\section{POLITICAL CRISIS \& TOURISM DESTINATIONS}

Several impacts are witnessed in tourism destinations that suffer from political instabilities whether within or in neighbouring countries; according to Ryu (Ryu, 2005) these include: sharp decline the international and domestic tourism volumes, loss of tourism income, lowering number of nights in tourism accommodations, cancellation of travel plans by individual and group tourists, flourishing of competing destinations due to negative tourists' flows, moreover, lack of interest to travel by tourists and foreign businesses due to perceiving the destination with an image of damage and risk, also fearing potential terrorist attacks. Such issues were investigated in previous literature (Magablih \& Mustafa, 2018; Ghaderi, Mat Som, \& Wang, 2014; Sausmarez, 2007; Neumayer, 2004; Apostolopoulos \& Ioannides, 1999; Sönmez \& Graefe, 1998).

The Arab Spring influence on Jordanian tourism sector is a multi-type of crisis; it's economic since tourist arrivals and revenues decreased; and reputational since it had dramatically caused a misperception of the country as an unsafe destination due to its location in the Middle East region. This signifies the need to effectively implement "Crisis Management", which according to Coombs (Coombs, 1999), seeks to prevent or lessen the negative outcomes of crisis and thereby protect the industry from damage.

\section{CRISIS MANAGEMENT}

Crisis management is all about "the preparation and application of strategies and tactics that can prevent or modify the impact of major events on the company or organization" (Stocker, 
1997, p. 189). Several models of crisis management of different stages were proposed in literature, of these: Murphy and Bayley's model (Murphy \& Bayley, 1989) (assessment, warning, impact, and recovery); Smith's crisis management model (Smith, 1990) (crisis of management, operational crisis and crisis of legitimation); Mitroff and Pearson model (Mitroff \& Pearson, 1993) (signal detection, probing/ preparation, business recovery, containment/ damage limitation and no-fault learning); Faulkner (Faulkner, 2001) (the pre-event phase (contingency plans and assessment studies are developed), prodromal phase (plans are activated after the occurrence of the crises, emergency phase (actions conducted to protect people and property), intermediate phase (media communication and rebuilding affected areas and infrastructure), and resolution phase (evaluation of crisis management process); Ritchie's crisis management framework (Ritchie, 2004) (prevention and planning, implementation, evaluation and feedback); Lyon and Worton's crisis management framework (Lyon \& Worton, 2007) (pre-event, warning signs, action, and review); and Murphy's strategic management framework (Murphy, 2008) (pre-crisis (crisis/ disaster prevention and planning), actual crisis (strategic implementation), and post crisis (resolution, evaluation and feedback). Based on the previously listed studies; it can be said that crisis management requires the implication of strategic planning (Evans \& Elphick, 2005; Ritchie, 2004), adapting a comprehensive research agenda and market recovery (Carlsen \& Liburd, 2008); effective communication (Marianna, 2011; Ritchie, 2004), preparing detailed contingency plans (Evans \& Elphick, 2005), and integration of stakeholders (Marianna, 2011; Blackman \& Ritchie, 2008; Ritchie, 2004). An effective model that was proposed for crisis management is the one of Four R's (Wilks \& Moore, 2003), which stands for distinct phases of a crisis: Reduction (detecting early warning signals), Readiness (preparing plans and running exercises), Response (executing operational and communication plans in a crisis situation), and Recovery (returning the organization to normal after a crisis). In such approach, an organization needs to identify potential crisis and conduct SWOT analysis (a survey of organization's internal strengths and weaknesses, and external opportunities and threats), this would help in identifying impacts and thus developing continuity and contingency plans to reduce the possibility and influence of a crisis. This should be followed by evaluating crisis exposure to develop strategic and communication plans, auditing and response exercises, controlling damage, pre-empting and reassuring stakeholders and the public, all are procedure to take place and acquire special managerial skills. Finally, recovery, continuity and learning lessons are the final stages in this process which would help to avoid future problems (Wilks and Moore, 2003). Based on this, the case study and its evaluation instrument were developed. As for the crisis' impacts, as well as crisis management procedures of communication, planning and coordination were the focal points addressed (see next two sections).

\section{THE CASE STUDY}

Started in Tunisia and Egypt and shortly after spread in some other Middle Eastern countries in 2010, the "Arab Spring" uprisings took place where fall of presidents and drastic instability in Tunisia, Egypt, Libya and Yemen were witnessed after protests against bad life conditions and corruption, while monarchies of Morocco and Jordan continued to be politically stable and adopted gradual political reforms (Masetti \& Körner, 2013). Deterioration of economic sectors in Middle East and North Africa region took place (OECD, 2011), as for tourism industry; there was a decline in the volume of inbound tourists, revenues, and hotels' occupancy rates.

Jordan was negatively influenced by the events of Arab Spring; there was a high level of trips cancellation by visitors from Europe and America, a drop in the number of tourist arrivals from 8,078,380 in 2010 to $6,812,438$ in 2011 (15.7\% decrease); a decrease of package tours from 707,735 to 419,571 (Ministry of Tourism and Antiquities, 2010). Since tourism is the largest export sector of the country, its second private sector employer, and a major producer of foreign exchange (Ministry of Tourism and Antiquities, 2003), and that it accounts for approximately $10.50 \%$ of the country's gross domestic product (GDP) (Central Bank of Jordan [CBJ], 2016), 
such declines in tourism are then critical to the Jordanian economy. A clear drop was witnessed in some particular markets, such as the ones from the Gulf Council countries (particularly from Saudi Arabia), and medical tourists, (mainly patients from Sudan, Libya, Yemen and Iraq). The tourism sector started to recover only in 2015. The Jordanian Ministry of Tourism and Antiquities and Jordan Tourism Board declared preparing an emergency plan (not formally published) to target markets as Gulf countries (Saudi Arabia and United Arab Emirates), Turkey and Far East (China, Japan and South Korea) (Jordan Times, 2015). There was also launching of online and offline campaigns to attract more of French, British, and German markets by linkages with European tour operators, advertisements on TV channels, taxis, and billboards, promoting the country as a film destination (The Martian movie was filmed in Wadi Rum, which was featured as Mars), promoting the usage of "Jordan Pass", which is a single ticket that allows tourists to access archaeological sites and museums while waiving entry visa fees for pass holders, waiving visa fees for packaged groups and individual travellers with a minimum stay of two consecutive nights, reduction of visa fees for all land borders, and waiving the departure tax for both Aqaba International Airport and Marka Civil Airport (Oddone, 2015). The formal website of Jordan Tourism Board gave access to live streaming cameras to experience views of distinguished locations; through videos, broadcasting tourists' commentaries about their experience in Jordan; also posting travel bloggers to recommend Jordan as a travel destination (Jordan Tourism Board, 2017). Agreements with charter flights firms by Jordan Tourism Board were signed to bring weekly flights from Europe to Jordan, A summer brochure "Jordan: the family destination" was launched and distributed in airports and at border crossings, enhancing attributes and tourism services in some historical sites, and supporting with marketing information technology training for small businesses, also reducing taxes on hotels (UNWTO, 2017). That is in addition to organizing and participation in different events and exhibitions (Eturbonews, 2017) (e.g. events news posted in Eturbonews website on different dates). The Jordanian formal authorities apparently concentrated on taking communication and containment actions to recover from drastic deterioration in tourism arrivals and revenues; unfortunately, no clear strategic planning approach nor a post-crisis research or SWOT analysis were declared or formally published when deciding these actions.

As mentioned above, this case study of Arab Spring and its influence on Jordanian tourism was presented for teaching purposes in a course entitled: "Tourism Crises Management". This case study was written and composed of the following parts: an introduction about the events of Arab Spring in Middle East and Jordan, indicators showing the decline in the volumes, revenues and accommodations' occupancies of Jordanian Tourism, then different actions taken by Jordanian authorities, this was followed by presenting different models of crisis management and similar cases of countries that could efficiently deal with political crises' impact on them as a tourism destinations. Such information was presented to students by a detailed text that was prepared from selected references by the instructor, also press releases and illustrative videos about different stakeholders expressing their opinions on this matter. Evaluating the effect of using case studies was tested through measuring levels of understanding and agreements on a quantified scale, which is explained in the next section.

\section{METHODOLOGY \& INSTRUMENT}

Developing a teaching case study is usually conducted through the following steps: developing objectives of teaching and gathering sufficient information on the tackled issue, writing, and structuring the case study to include: an interesting reflective title, an introduction that sheds the light on the problem and parties involved, the main body that includes the story, and exhibits as the case require to make reader know extra information. In addition, setting teaching notes, which give insights on how to use and prepare for the case study, sources of additional information and criteria used to evaluate students, all should be considered (Balakrishnan, 2010). When presenting the case study to class, key concepts should be identified and clarified, students are then asked to work in 
groups and participate in a discussion where they are inquired to give their suggested solutions to the case. The teacher facilitates the discussion by asking questions to make the reasoning behind the suggested solutions, and evaluate them (Giacalone, 2016). Finally, assessment of case studies takes place for formative and summative purposes (Biggs \& Tang, 2011). Evaluating the effectiveness of case studies in teaching can be done by different methods: surveys measuring levels of understanding and agreements on quantified scales (Bonney, 2015; Iahad, Mirabolghasemi, Mustaffa, Abd. Latif, \& Buntat, 2013), measuring attitudes of students toward an issue (Akengin \& Aydemir, 2012), and comparing results gained by students in evaluation of courses they take (Pilato \& Ulrich, 2014). Experiment vs. control groups or pre vs. post using case study are approaches to be used as well for comparisons among different groups involved.

For this paper, all the previously mentioned steps for develoing the case study, as well as measuring levels of agreement and making comparisons on quantified scales were used.

A sample of 42 students were targeted for this study, they were taking the course of 'Tourism Crises Management', the students anonymously completed a questionnaire before and after the case study was presented by the instructor, where a paired t-test was intended to test statistical differences for the influence of case study as a teaching method in the topic of tourism crisis management (note: no grades were given to students for participating in filling the questionnaire).

The questionnaire included the following sections: the first was for information about students as gender ( 28 were females and 13 were males as valid responses), study level (first year: 1, second year: 4 , third year: 19 , and fourth year: 18 ), and if they have worked in tourism sector (only 6 of the 42 had a positive response to this question). The second section was composed of two indices that measured agreement on a five-point Likert scale (1: Strongly disagree, 2: Disagree, 3: Neutral, 4: Agree; 5: Strongly Agree) for statements about the impact of Arab Spring on Jordanian tourism sector and the performance of different stakeholders in dealing with such crisis. Table 1 shows the descriptive statistics of these variables. The index of impact had a Cronbach alpha of 0.61 , while the index of performance had a Cronbach alpha of 0.79 . As for validity, face validity was applied by reviewing the questionnaire by professors of tourism in public Jordanian universities.

\section{ANALYSIS \& RESULTS}

It is noticed that variables in the index of Arab Spring Impact were of mean scores within: (3: Neutral - 4: Agree) and (4: Agree - 5: Strongly agree); the variables with the highest means were for the significant decrease in the numbers of incoming tourists, significant decrease in tourism revenues and for significant decrease in the numbers of offered direct tourism job opportunities. As for the variables in the index of Jordanian Tourism Sector Performanc, the means were mostly within (2: Disagree -3 Neutral); the variables with the highest means were the ones of modifying the mareting plans and the effective coordination among tourism sector stakeholders to deal with such crisis (table 1).

A paired T-test was conducted to examine the differences between levels of agreements by students before and after presenting the case study of Arab Spring Crisis and its influence on Jordanian tourism. The results show that the following variables had significant statistical differences: having alternative destinations other than Jordan $(\mathrm{t}=-2.376, \mathrm{p}=.022)$; having a significant change in tourism markets $(\mathrm{t}=-2.804, \mathrm{p}=.008)$; having a significant decrease in tourists' length of stay $(\mathrm{t}=-3.408, \mathrm{p}=.002)$; having a significant decrease in tourists' spending $(\mathrm{t}=-3.045$, $\mathrm{p}=.004)$; having a significant increase in the numbers of domestic tourists $(\mathrm{t}=-2.045, \mathrm{p}=.047)$; following a clear planning approach by Ministry of Tourism and Antiquities (MOTA) with the involvement of relevant stakeholders to deal with such crisis $(\mathrm{t}=2.493, \mathrm{p}=.017)$; showing Ministry of Tourism and Antiquities (MOTA) a great readiness in dealing with the current crisis through effective communication with relevant stakeholders $(\mathrm{t}=2.211, \mathrm{p}=.033)$; and that Jordan Tourism Board (JTB) had clearly modified its marketing plans to deal with the current crisis $(\mathrm{t}=2.263, \mathrm{p}=$ .029) (table 1). 
Table 1. Descriptive statistics and T-test comparisons between responses of students before and after presenting the case study of Arab Spring (*P-values are significant at the level of .05 or below)

\begin{tabular}{|c|c|c|c|c|c|}
\hline \multirow[t]{2}{*}{ Variables } & \multirow{2}{*}{$\begin{array}{l}\mathrm{N} \text { of valid } \\
\text { responses }\end{array}$} & Before & After & \multirow{2}{*}{$\begin{array}{c}\mathrm{T} \\
\text { Value }\end{array}$} & \multirow{2}{*}{$\begin{array}{c}\mathrm{P} \\
\text { Value }\end{array}$} \\
\hline & & Mean (SD) & Mean (SD) & & \\
\hline \multicolumn{6}{|c|}{ Impact Index } \\
\hline $\begin{array}{l}\text { The misperception of Jordan as a tourism destination } \\
\text { after Arab Spring events caused a significant decrease } \\
\text { in the numbers of incoming tourists. }\end{array}$ & 41 & $\begin{array}{c}4.5366 \\
(0.67445)\end{array}$ & $\begin{array}{c}4.7317 \\
(0.44857)\end{array}$ & -1.748 & .088 \\
\hline $\begin{array}{l}\text { The misperception of Jordan as a tourism destination } \\
\text { after Arab Spring events caused a significant decrease } \\
\text { in tourism revenues }\end{array}$ & 41 & $\begin{array}{c}4.4878 \\
(0.77852)\end{array}$ & $\begin{array}{c}4.5854 \\
(0.66991)\end{array}$ & -.726 & .472 \\
\hline $\begin{array}{l}\text { The misperception of Jordan as a tourism destination } \\
\text { after Arab Spring events caused a significant decrease } \\
\text { in the numbers of offered direct tourism job } \\
\text { opportunities. }\end{array}$ & 40 & $\begin{array}{c}4.35 \\
(0.8638)\end{array}$ & $\begin{array}{c}3.975 \\
(0.80024)\end{array}$ & .190 & .850 \\
\hline $\begin{array}{l}\text { The misperception of Jordan as a tourism destination } \\
\text { after Arab Spring events caused a partial tourism un- } \\
\text { employability }\end{array}$ & 40 & $\begin{array}{c}3.825 \\
(0.87376)\end{array}$ & $\begin{array}{c}3.8537 \\
(1.33343)\end{array}$ & -.813 & .421 \\
\hline $\begin{array}{l}\text { The misperception of Jordan as a tourism destination } \\
\text { after Arab Spring events led to having alternative } \\
\text { tourism destinations other than Jordan }\end{array}$ & 41 & $\begin{array}{c}3.439 \\
(1.24597)\end{array}$ & $\begin{array}{c}3.878 \\
(1.00487)\end{array}$ & -2.376 & $.022^{*}$ \\
\hline $\begin{array}{l}\text { The misperception of Jordan as a tourism destination } \\
\text { after Arab Spring events caused a significant change in } \\
\text { tourism markets }\end{array}$ & 41 & $\begin{array}{c}3.4878 \\
(0.8403)\end{array}$ & $\begin{array}{c}3.5366 \\
(1.20618)\end{array}$ & -2.804 & $.008^{*}$ \\
\hline $\begin{array}{l}\text { The misperception of Jordan as a tourism destination } \\
\text { after Arab Spring events caused closing of several } \\
\text { tourism services }\end{array}$ & 41 & $\begin{array}{c}3.3902 \\
(0.94546)\end{array}$ & $\begin{array}{c}4.1951 \\
(0.98029)\end{array}$ & -.829 & .412 \\
\hline $\begin{array}{l}\text { The misperception of Jordan as a tourism destination } \\
\text { after Arab Spring events caused a significant decrease } \\
\text { in the tourists' length of stay }\end{array}$ & 41 & $\begin{array}{c}3.5366 \\
(1.16399)\end{array}$ & $\begin{array}{c}3.9268 \\
(1.2528)\end{array}$ & -3.408 & $.002^{*}$ \\
\hline $\begin{array}{l}\text { The misperception of Jordan as a tourism destination } \\
\text { after Arab Spring events caused a significant decrease } \\
\text { in tourists spending (mainly incoming tourists) }\end{array}$ & 41 & $\begin{array}{c}3.2195 \\
(1.19399)\end{array}$ & $\begin{array}{c}3.4634 \\
(1.22673)\end{array}$ & -3.045 & $.004 *$ \\
\hline $\begin{array}{l}\text { The misperception of Jordan as a tourism destination } \\
\text { after Arab Spring events caused a significant decrease } \\
\text { in the numbers of outgoing/ outbound tourists. }\end{array}$ & 41 & $\begin{array}{c}3 \\
(1.18322)\end{array}$ & $\begin{array}{c}3.6341 \\
(1.17805)\end{array}$ & -.565 & .575 \\
\hline $\begin{array}{l}\text { The misperception of Jordan as a tourism destination } \\
\text { after Arab Spring events led to an increase in the } \\
\text { numbers of domestic tourists }\end{array}$ & 41 & $\begin{array}{c}3.5122 \\
(1.24744)\end{array}$ & $\begin{array}{c}4.7317 \\
(0.44857)\end{array}$ & -2.045 & $.047^{*}$ \\
\hline \multicolumn{6}{|c|}{ Performance Index } \\
\hline $\begin{array}{l}\text { The Jordanian Ministry of Tourism and Antiquities } \\
\text { (MOTA) has shown a great readiness in dealing with } \\
\text { the current crisis through effective communication } \\
\text { with relevant stakeholders }\end{array}$ & 39 & $\begin{array}{c}2.9487 \\
(1.0748)\end{array}$ & $\begin{array}{c}2.4359 \\
(1.31379)\end{array}$ & 2.211 & $.033^{*}$ \\
\hline $\begin{array}{l}\text { The Jordanian Ministry of Tourism and Antiquities } \\
\text { (MOTA) has followed a clear planning approach with } \\
\text { the involvement of relevant stakeholders on how to } \\
\text { deal with current crisis }\end{array}$ & 40 & $\begin{array}{c}2.875 \\
(0.88252)\end{array}$ & $\begin{array}{c}2.325 \\
(1.22762)\end{array}$ & 2.493 & $.017^{*}$ \\
\hline $\begin{array}{l}\text { Jordan Tourism Board (JTB) clearly modified its } \\
\text { marketing plans to deal with the current crisis. }\end{array}$ & 40 & $\begin{array}{c}3.1 \\
(0.92819)\end{array}$ & $\begin{array}{c}2.575 \\
(1.3939)\end{array}$ & 2.263 & $.029 *$ \\
\hline $\begin{array}{l}\text { Tourism stakeholders were ready to deal with current } \\
\text { crisis since they had contingency plans. }\end{array}$ & 40 & $\begin{array}{c}2.875 \\
(0.85297)\end{array}$ & $\begin{array}{c}2.6 \\
(1.194)\end{array}$ & 1.380 & .176 \\
\hline $\begin{array}{l}\text { There was an effective coordination among tourism } \\
\text { sector stakeholders to deal with such crisis }\end{array}$ & 41 & $\begin{array}{c}3.1707 \\
(0.97217)\end{array}$ & $\begin{array}{c}2.7561 \\
(1 .) 35611\end{array}$ & 1.811 & .078 \\
\hline
\end{tabular}


As for the variables with non-significant $p$ values (>.05), these were the ones in impact index concerning the decreases in: numbers of incoming tourists, revenues, offered jobs, employability, number of operating services and numbers of outgoing or outbound tourists; also for the 2 performance variables related to having contingency plans by tourism stakeholders and effective coordination among them. Such non-significance is justified since such aspects were widely covered and disseminated through mass media. Moreover, the $t$ values have shown to be mostly negative for variables in the index of impact, indicating then higher levels of awareness and agreement on the negative consequences of the crisis on Jordanian tourism. This was not the same though for the index of performance, the positive $t$ values mean that evaluations by students were of higher levels toward agreement.

\section{CONCLUSIONS}

Overall, the descriptive statistics have shown that case study approach helped in making students more aware about the influence of Arab Spring on Jordanian tourism, moreover, it helped students in re-evaluating the procedures taken by tourism authorities in dealing with such crisis. Explaining the drastic changes in Jordanian tourism levels caused by Arab Spring events, presenting literature on crisis management models and similar cases of other countries helped in achieving such results. The small size of the sample is a limitation to this study, though, the number of students in a class is not to be a controlled factor by the researcher.

To make students (future employees and managers in tourism sites/establishments) acquainted with such skills, this requires using effective learning methods that help in recognizing the nature and consequences of different crises, also different means to deal with them; therefore, case studies become then one of the best approaches for such purpose. Case studies are examples that give insight into problems with illustrating main ideas (Fry, Ketteridge, \& Marshall, 1999). According to Richardson (Richardson, 1993), case studies introduce problems and provoke the search for solutions, provide a 'halfway house' between abstract concepts and real life experience, help in learning from past mistakes, thus making better decisions on ways to act, help in explaining the past, understanding the present, and predicting the future, which will then lessen disturbance caused by unexpected events and ambiguity of crises, also the confusion resulting from the involvement of numerous stakeholders. This requires then empathetic managerial styles, sophisticated communication, and group decision-making skills.

In the context of tourism (as in the case of this study), there are advantages and disadvantages that characterise the use of case studies, as for advantages: the relevance of information to actors involved in tourism development and management, the depth of information related to impacts influencing economy and businesses, the interactive nature of this method, and the ability to track the issue over a long period of time (past and present), all of these emphasize the need to be neutral and to consider all stakeholders' points of view when developing a case of study. Unfortunately, the lack of studies or published material on strategies adopted to deal with crises by different stakeholders would make building such neutral and comprehensive case study difficult to achieve. Despite this, the case study presented in this context not only helped student in gaining better understanding of consequences resulted from Arab Spring crisis on Jordanian tourism, but also of procedures to be taken by different stakeholders during the time of crises. Students also recognized that a more proactive and comprehensive approach should be followed by Jordanian tourism authorities in planning for crises; the concept of crisis management should be integrated in national strategies of tourism sector; this becomes important since there is a clear absence of such aspect (i.e. MOTA National Strategies of the years: 2004-2010; 2011-2015 and 2015-2025) (Ministry of Tourism and Antiquities, 2015; Ministry of Tourism and Antiquities, 2010; Ministry of Tourism and Antiquities, 2003). In such strategies, the priority is given in the first place to diversification of tourism product, targeting new markets, increasing competitiveness through promotion and enhancement of human resources, and enhancing the image of the country as a tourism destination. 
Different future implications can be suggested based on the results of this study; training programs can be developed where both public sector and educational institution participate in to acquaint students with necessary knowledge on crisis management. Another implication is establishing a guide by tourism authorities in Jordan where a system for dealing with different types of crises is made as reference for both decision makers and educational establishments, this become important since the country was and is still exposed to different types of crises due to its location in the turbulent Middle East region. Mostly important, crisis management plans should be developed, declared, and made available for discussion in events where the participation of academics and students would add value to both the quality of these plans and educational experience of the public.

\section{REFERENCES}

Akengin, H., \& Aydemir, G. (2012). Effects of using case-study method in social studies on Students' Attitudes Towards Environment. International Electronic Journal of Environmental Education, 2(2), 119-127.

Anderson, L., \& Krathwohl, D. (2000). A taxonomy for learning, teaching, and assessing: a revision of bloom 's taxonomy of educational objectives, complete edition. New York: Longman Publishing Group, White Plains.

Apostolopoulos, Y., \& Ioannides, D. (1999). Political instability, war, and tourism in Cyprus: the effects management, and prospects for recovery. Journal of Travel Research, 38(1), 51-57.

Badger, J. (2010). Classification and framing in the case method: discussion leaders' questions. Journal of Further and Higher Education, 34(4), 503-518.

Balakrishnan, M. (2010). Writing Cases. Retrieved January 18, 2019, from http://www.emeraldgrouppublishing.com/products/new/pdf/teaching_cases.pdf

Bennett, N., \& Cornely, K. (2001). Thalidomide makes a comeback: A case discussion exercise that integrates biochemistry and organic chemistry. Journal of Chemical Education, 78(6), 759-761.

Biegel, C., Lee, L., \& Graveel, J. (1998). Muskegon County wastewater management: An effluent application decision case study: (Case study). Journal of Natural Resources and Life Sciences Education, 27, 137144.

Biggs, J., \& Tang, C. (2011). Teaching for quality learning at university (4th ed.). New York: Open University Press - McGraw Hill Education.

Blackman, D., \& Ritchie, B. (2008). Tourism crisis management and organizational learning. Journal of Travel and Tourism Marketing, 23(2-4), 45-57.

Bloom, B., Engelhart, M., Furst, E., Hill, W., \& Krathwohl, D. (1956). Taxonomy of educational objectives, handbook I: the cognitive domain. New York: David McKay Co Inc.

Bonney, K. (2015). Case study teaching method improves student performance and perceptions of learning gains. Journal of Microbiology and Biology Education, 16(1), 21-28.

Budden, C., \& Budden, M. (2010). Developing crisis management skills through a realistic case scenario. Journal of Business Case Studies, 6(6), 131-134.

Camill, P. (2000). Using journal articles in an environmental biology course. Journal of College Science Teaching, 30(1), 38-43.

Carlsen, J., \& Liburd, J. (2008). Developing a research agenda for tourism crisis management, market recovery and communications. Journal of Travel and Tourism Marketing, 23(2-4), 265-276.

Carlson, J., \& Schodt, D. (1995). Beyond the lecture: case teaching and the learning of economic theory. Journal of Economic Education, 26(1), 17-28.

Cheng, V. (1995). An environmental chemistry curriculum using case studies. Journal of Chemical Education, 72(6), 525-528.

Cliff, W. (2006). Case study analysis and the remediation of misconceptions about respiratory physiology. Advances in Physiology Education, 30(4), 215-223.

Coombs, V. (1999). Ongoing crisis communication: planning, managing, and responding. California: Sage Publications, Inc.

Cornely, K. (1998). Use of case studies in an undergraduate biochemistry course. Journal of Chemical Education, 75(4), 475-478. 
Dayal, A., Van Eerden, P., Gillespie, L., Katz, N., Rucker, L., \& Wylie Rosett, J. (2008). Case-based nutrition teaching for medical students. Journal of Nutrition Education and Behaviour, 40(3), 191-192.

Eturbonews. (2017). Several articles on tourism in Jordan after Arab Spring. Retrieved 2017-2018, from https://www.eturbonews.com/?s=Jordan+Arab+Spring

Evans, N., \& Elphick, S. (2005). Models of crisis management: an evaluation of their value for strategic planning in the international travel industry. International Journal of Tourism Research, 7(3), 135-150.

Faulkner, B. (2001). Towards a framework for tourism disaster management. Tourism Management, 22(2), 135-147.

Fry, H., Ketteridge, S., \& Marshall, S. (1999). A Handbook for Teaching and Learning in Higher Education. Glasgow: Kogan Page.

Gelman, C., \& Mirabito, D. (2005). Practicing what we teach: using case studies from 9/11 to teach crisis intervention from a generalist perspective. Journal of Social Work Education, 41(3), 479-494.

Ghaderi, Z., Mat Som, A., \& Wang, J. (2014). Organizational Learning in Tourism Crisis Management: An experience from Malaysia. Journal of Travel and Tourism Marketing, 31(5), 627-648.

Giacalone, D. (2016). Enhancing student learning with case-based teaching and audience response systems in an interdisciplinary Food Science course. Higher Learning Research Communications, 6(3). doi:https://doi.org/10.18870/hlrc.v6i3.304

Golich, V., Boyer, M., Franco, P., \& Lamy, S. (2000). The ABC's of case teaching. International Studies Perspectives, 1(1), 11-29.

Grant, R. (1997). A claim for the case method in the teaching of geography. Journal of Geography in Higher Education, 21(2), 171-185. doi:http://dx.doi.org/10.1080/03098269708725423

Herreid, C., Schiller, N., Herreid, K., \& Wright, C. (2011). In case you are interested: results of a survey of case study teachers. Journal of College Science Teaching, 40(4), 76-80.

Iahad, N., Mirabolghasemi, M., Mustaffa, N., Abd. Latif, M., \& Buntat, Y. (2013). Student perception of using case study as a teaching method. Procedia Social and Behavioural Sciences, 93(1), 200-204.

Jordan Times. (2015, July 21). Jordan battling to rejuvenate tourism sector. Retrieved March 11, 2016, from http://www.jordantimes.com/news/local/jordan-battling-rejuvenate-tourism-sector

Jordan Tourism Board. (2017). The Blog webpage of Jordan Tourism Board. Preluat pe November 25, 2017, de pe https://international.visitjordan.com/Blog

Key, S. (1997). Teaching managers to respond ethically to organizational crises: an inquiry into the case method. Teaching Business Ethics, 1(2), 197-211.

Killen, R. (2006). Effective teaching strategies: lessons from research and practice. Melbourne: Social Science Press.

Knechel, W. (1992). Using the case method in accounting instruction. Issues in Accounting Education, 7(2), 205-217.

Lyon, A., \& Worton, A. (2007). A proposed model for tourism crisis management: The UK's Foot and Mouth Disease crisis analysed. In E. Laws, B. Prideaux, \& K. Chon, Crisis management in Tourism (pp. 200216). London: CABI International.

Magablih, K., \& Mustafa, M. (2018). How the "Arab Spring" influenced tourism and hospitality industry in Jordan: perceptions of workers in tourism and hospitality business. Journal of Tourism and Hospitality Management, 6(2), 132-139.

Marianna, S. (2011). Social media and crisis management in tourism: applications and implications for research. Information Technology and Tourism, 13(4), 269-283.

Masetti, O., \& Körner, K. (2013). Two years of Arab Spring: where are we now? what's next? Series of Current Issues Emerging Markets. Deutsche Bank.

Mayo, J. (2004). Using case-based instruction to bridge the gap between theory and practice in psychology of adjustment. Journal of Constructivist Psychology, 17, 137-146.

McGuire, S., \& Whaley, G. (2017). Guidelines for writing a management teaching case study. Journal of Case Research and Inquiry, 2(1), 236-272.

Ministry of Tourism and Antiquities. (2003). National Tourism Strategy (2004-2010). Ministry of Tourism and Antiquities. Preluat pe November 25, 2017, de pe http://www.tourism.jo/Contents/National_StrategiesAr.aspx

Ministry of Tourism and Antiquities. (2010). National Tourism Strategy (2011-2015). Ministry of Tourism and Antiquities and USAID/Jordan. Preluat pe June 2, 2018, de pe http://www.tourism.jo/Contents/National_StrategiesAr.aspx 
Ministry of Tourism and Antiquities. (2010). Statistical Bulletins available on the official website of Ministry of Tourism and Antiquities (2010-2015). Preluat pe March 12, 2016, de pe http://www.mota.gov.jo

Ministry of Tourism and Antiquities. (2015). Ro'ya al-Urdun 2025 (Vision of Jordan-Arabic). Jordanian Government. Preluat pe November 25, 2017, de pe http://www.tourism.jo/Contents/National_StrategiesAr.aspx

Mitroff, I., \& Pearson, C. (1993). Crisis management: A diagnostic guide for improving your organization's crisis-preparedness (1st ed.). San Francisco: Jossey-Bass.

Murphy, P. (2008). Oxford: Elsevier.

Murphy, P., \& Bayley, R. (1989). Tourism and disaster planning. The Geographical Review, 79(1), 36-46.

Mustoe, L., \& Croft, A. (1999). Motivating engineering students by using modern case studies. European Journal of Engineering Education, 15(6), 469-476.

Neumayer, E. (2004). The Impact of Political Violence on Tourism. Journal of Conflict Resolution, 48(2), 259281.

Ngcobo, M. (2008). On account of a basket: a socio-historical and ethnographic perspective on the development of multilingualism in South Africa. African Journal of Indigenous Knowledge Systems, 7(1), 7-22.

Oddone, E. (2015). Bringing them back: boosting Jordan's ailing visitor numbers. Retrieved December 22, 2017, from http://www.venturemagazine.me/2015/12/bringing-them-back-boosting-jordans-ailingvisitor-numbers/

OECD. (2011). Socio-economic context and impact of the 2011 events in the Middle East and North Africa region, MENA-OECD Investment Programme. Retrieved March 11, 2016, from http://www.oecd.org/mena/competitiveness//49171115.pdf

Olkun, S., Altun, A., \& Deryakulu, S. (2009). Development and evaluation of case-based digital learning tool about children's mathematical thinking for elementary school teachers (L-TEST). European Journal of Teacher Education, 32(2), 151-165.

Pilato, B., \& Ulrich, M. (2014). Is the case study method an effective pedagogical method for students to learn the fundamentals of financial accounting? ASBBS Annual Conference, 21, pp. 541-554. Las Vegas. Retrieved January 18, 2019, from http://asbbs.org/files/ASBBS2014/PDF/P/Pilato_Ulrich(P541554).pdf

Richardson, B. (1993). Why we need to teach crisis management and to use case studies to do it. Management Education and Development, 24(2), 138-148.

Ritchie, B. (2004). Chaos, crises and disasters: a strategic approach to crisis management in the tourism industry. Tourism Management, 25(1), 669-683.

Ryu, S. (2005). Political instability and its effects on tourism. Retrieved August 18, 2019, from https://www.besteducationnetwork.org/Papers_Presentations/2169

Sandstorm, S. (2006). Use of case studies to teach diabetes and other chronic illnesses to nursing students. Journal of Nursing Education, 45(6), 229-232.

Sausmarez, N. (2007). The Potential for Tourism in Post-Crisis Recovery: Lessons from Malaysia's Experience of the Asian Financial Crisis. Asia Pacific Business Review, 13(2), 277-299.

Shaw, M. (2018). Teaching campus crisis management through case studies: moving between theory and practice. Journal of Student Affairs Research and Practice, 55(3), 308-320.

Sivan, A., Wong Leung, R., Woon, C., \& Kember, D. (2000). An implementation of active learning and its effect on the quality of student learning. Innovations in Education and Training International, 37(4), 381-389.

Smith, D. (1990). Beyond contingency planning: towards a model of crisis management. Industrial Crisis Quarterly, 4, 263-275.

Sönmez, S., \& Graefe, A. (1998). Influence of Terrorism Risk on Foreign Tourism Decisions. Annals of Tourism Research, 25(1), 112-144.

Stocker, K. (1997). A Strategic approach to crisis management. In C. Caywood, The Handbook of strategic public relations and integrated communications (pp. 189-203). New York: McGraw-Hill.

UNWTO. (2017). Al Multaqua Ballroom, Arabian Travel Market (ATM), Dubai, Monday, 24 April 2017, forty second meeting. UNWTO Commission for the Middle East. Retrieved December 25, 2017, from http://middle-east.unwto.org/event/42nd-meeting-unwto-commission-middle-east

Wilks, J., \& Moore, S. (2003). Tourism risk management for the Asia Pacific region: an authoritative guide for the managing crises and disasters. Retrieved October 3, 2019, from https://sustain.pata.org/wpcontent/uploads/2015/02/Wilks_TourismRiskMgt-FINALv02.pdf 
Woods, D. (1996). Problem-based learning for large classes in chemical engineering. In L. Wilkerson, \& W. Gijselaers, Bringing problem-based learning to higher education: theory and practice (pp. 91-99). San Francisco: Jossey-Bass.

Yadav, A., Shaver, G., \& Meckl, P. (2010). Lessons learned: implementing the case teaching method in a mechanical engineering course. Journal of Engineering Education, 99(1), 55-69.

Submitted:

December 14, 2020
Revised:

September 19, 2021
Accepted and published online

October 14, 2021 